\title{
LAÇOS MATRIMONIAIS, AMARRAS TRADICIONAIS: a família como autoconstituição em Câmara Cascudo'
}

\author{
Ramonildes Alves Gomes* \\ Valdeci Feliciano Gomes*
}

\begin{abstract}
O objetivo deste artigo é analisar a biografia de Luís da Câmara Cascudo, procurando compreender o alicerce histórico e social a partir do qual esse folclorista legitimou posicões sobre seu pai e sua mãe e definiu papéis para homens, mulheres e família na sociedade nordestina. Portanto, Câmara Cascudo não é só aquilo que ele diz sobre si próprio, em suas biografias e obras, mas também, o que os outros disseram sobre ele. Os argumentos construídos pelo próprio são o resultado de relações de múltiplos interesses. Foi se relacionando com uns e se contrapondo a outros que esse regionalista se constituiu como sujeito histórico. Trabalhando com a memória, compreendendo que ela nem sempre é uma elaboração ingênua e desinteressada, por ser seletiva, analisaremos a constituição do sujeito Câmara Cascudo e seus outros. PALAVRAS-CHAVE: família, intersubjetividade, memória, gênero.
\end{abstract}

\section{INTRODUÇÃO}

O relato, seja ele biográfico ou autobiográfico, como o do investigado que se entrega a um investigador, propõe acontecimentos que, sem terem se desenrolado sempre em sua estrita sucessão cronológica (quem já colidiu histórias de vida sabe que os investigados perdem constantemente o fio da estrita sucessão do calendário), tendem ou pretendem organizar-se em consequências ordenadas segundo relações inteligíveis (Bourdieu, 1996, p.184).

Segundo Bourdieu, falar de uma história de vida é supor que a vida é uma história, ou um conjunto de acontecimentos individuais pensados como parte da história, e que ela se associa a um caminho, a um deslocamento composto por etapas, por uma sucessão de acontecimentos. Ele fala

"Doutora em sociologia, Professora do Programa de PósGraduação em Ciências Sociais (PPGCS-UFCG).

Rua Aprígio Veloso, 882. Cidade Universitária. Cep: 58.100000. Campina Grande - Paraiba - Brasil. rnildes@hotmail.com

${ }^{* *}$ Mestrando do Programa de Pós-Graduação em Ciências Sociais (PPGCS/UFCG).valdeci_feliciano@yahoo.com.br

${ }^{1}$ Este trabalho é o resultado das discussões realizadas durante a disciplina Família Gênero e Sexualidade no semestre 2006/1, as quais ampliaram o escopo da análise para compreensão de categorias até então pouco exploradas na obra de Câmara Cascudo. do cuidado que devem ter aqueles que trabalham com a biografia, com essa teoria que concebe a vida como um conjunto orientado, como um seguimento, um projeto que, em todos os atos, se justifica pelo seu cumprimento. Pois há relatos biográficos e autobiográficos organizados nessa lógica, que consideram os acontecimentos como uma sucessão cronológica, com ações sempre organizadas como se fossem construir o objeto que a biografia se propõe a formar. E, dessa forma, certos acontecimentos são selecionados e outros excluídos para dar coerência à construção pretendida pelo autor ou autores da biografia que querem conformar.

Nesse sentido, Giovanni Levi (1996, p.160) diz que a dificuldade de escrever sobre a vida de um indivíduo não é a falta de fontes, mas o fato de nós, como historiadores e sociólogos, imaginarmos que os atores sociais obedecem a um modelo de racionalidade anacrônico e limitado, como se suas ações não estivessem dentro de um contexto temporal e espacial, mas organizados numa coerência sincrônica que supera as datações. Afirma também que, ao seguirmos uma tradição biográfica estabelecida, contentamo-nos com modelos que se associam uma cronologia ordenada, 
de modo a dar plausibilidade a uma personalidade coerente e estável.

Câmara Cascudo orientou sua biografia também numa ordem cronológica e lógica, fazendo uso dos fatos que o marcaram como intelectual e folclorista. Para se constituir como tal, organizou sua história com certa coerência, construindo-se como sujeito e objeto de seu estudo, pesquisando uma cultura popular que, segundo ele, fez parte da sua vivência. Por isso, no estudo da biografia, é preciso também inquietar-se diante de certos recortes ou agrupamentos com que nos familiarizamos, para arrancá-los de sua quase evidência e reconhecer que eles talvez não sejam, afinal de contas, o que se acreditava que fossem no primeiro olhar.

Câmara Cascudo não é só aquilo que ele diz sobre si próprio em suas biografias e obras, ${ }^{2}$ mas também o que os outros disseram sobre ele. ${ }^{3}$ É o resultado de uma relação múltipla de interesses. Foi se relacionando com uns e se contrapondo a outros que Câmara Cascudo se constituiu como sujeito histórico. Por isso, nossa pretensão é a de compreender o discurso acerca da mulher e da família patriarcal a partir das relações que o folclorista estabelece com os outros, ou com aqueles que o apoiavam, ou com os que falavam sobre ele - uma narrativa de Câmara Cascudo referida a seus outros.

Este artigo é dedicado ao estudo da biografia de Luís da Câmara Cascudo, porém não para falar do sujeito histórico, que fortalece e constrói uma imagem dentro de uma lógica retrospectiva e prospectiva. O objetivo é entender como, na elaboração de sua história de vida, o folclorista difunde um discurso sobre sua família, ao tempo em que demarca as posições de seu pai, de sua mãe e a sua própria, definindo os papéis assumi-

"Como "O tempo e eu (confidências e proposições)", "Ontem: imaginações e notas de um professor de província", "Seleta”, "Coisas que o povo diz", "Civilização e Cultura", "Anúbis e outros ensaios", "Literatura oral do Brasil", "Tradição e ciência do povo", "Vaqueiros e cantadores", "Rede-de-dormir".

${ }^{3}$ Lima, Diógenes da Cunha. "Câmara Cascudo, um brasileiro feliz", Costa, Américo de Oliveira. "Viagem ao universo de Câmara Cascudo", Oliveira, Gibson. "Câmara Cascudo: um homem chamado Brasil”, Maranhão, Djalma. "Cascudo, mestre do folclore Brasileiro". dos pelo o homem e pela mulher em determinado modelo de família. ${ }^{4}$

Utilizamos como instrumental metodológico o material biográfico, rejeitando a interpretação unívoca das trajetórias individuais, indicando os novos caminhos trilhados pelos que procuram utilizar a biografia como instrumento de conhecimento histórico e sociológico, e substituindo a tradicional biografia linear e factual. Para isso, a reconstituição do contexto histórico e social em que se desenrolam os acontecimentos marcantes na trajetória de vida desse regionalista permite compreender o que, à primeira vista, parece inexplicável e desconcertante. O trabalho com a memória permite entender que nem sempre a elaboração das imagens do passado é inocente e natural, pois a memória é seletiva: nem tudo fica gravado, nem tudo fica registrado. Ela sofre flutuações em função do momento em que é articulada.

Pretendemos, ao longo do trabalho, situar algumas das produções literárias de Câmara Cascudo no contexto histórico vivenciado por sua família, focalizando a análise e o questionamento dos valores patriarcais e tradicionais dominantes naquele momento. Problematizaremos o modo como ele produziu esses discursos, tomando por base a distinção entre os lugares de seu pai e de sua mãe, e, ao mesmo tempo, como legitimou os papéis diferenciados e hierarquizados entre homens e mulheres em sua biografia e em suas obras.

\section{O CONTEXTO DE VIDA E DA OBRA DE CÂMA- RACASCUDO}

Nos anos 20 e 30 do século XX, os romances sobre o Nordeste anunciam que havia algo de estranho no ar: a fumaça deixava lentamente de sair pelo bueiro dos engenhos e ganhava espaço na nova chaminé, redonda, enorme e vermelha da

\footnotetext{
4 A compreensão de família patriarcal que adotaremos neste texto refere-se a um tipo fixo de família em que os personagens, uma vez definidos, apenas se substituem no decorrer das gerações, em nada ameaçando a sua hegemonia, e a um tronco de onde brotam todas as outras relaçôes sociais (Corrêa, 1993, p.15)
} 
usina. ${ }^{5}$ A paisagem se modificava. Era o perigo do progresso que avançava sobre o campo. As antigas casas-grandes e as senzalas foram sendo derrubadas. Os rios, antes "respeitados", eram poluídos. A expansão do usineiro (o moderno) representava a extinção dos engenhos (o tradicional). A diferença era do céu para o inferno, pois o usineiro só se importava com as coisas da cidade, e o campo passava a ser apenas o local de trabalho. As máquinas da usina trouxeram o desemprego, a fome e a miséria dos antigos trabalhadores, restando-lhes apenas a lembrança do antigo senhor de engenho.

Em um período de quase 50 anos, da implantação da República até a década de 30, o cenário histórico e político anunciado pelos romances regionais não registra mudanças substanciais. Com a emergência do "coronel", o mandonismo local (homens da boa governança da terra) aumenta seu poder de barganha, em decorrência da nova representação político-eleitoral. Contudo, esse mesmo poder local teve sua autonomia afetada com a proximidade entre o campo e a cidade, propiciada pela modernização dos meios de transportes, o aumento do fluxo de informações, e, por último, pelo aumento da interdependência das atividades produtivas. Tudo isto ressignifica o que é rural e o que é urbano. Constata-se também a progressiva integração no sistema econômico global de áreas do sertão, antes relativamente marginalizadas, com

${ }^{5}$ Rego, José Lins do. "Usina”. 13.ed. Rio de Janeiro: José Olympio, 1993. Em nota introdutória a "Usina”, em 1926, quando fala do ciclo da cana-de-açúcar, o próprio escritor depõe sobre a origem primeira de suas narrativas ao escrever: "A história desses livros é bem simples comecei querendo escrever apenas memórias que fossem de todos os meninos criados nas casas-grandes dos engenhos nordestinos”. Ele nos diz como ultrapassou esse propósito: "sucede, porém, que um romancista é muitas vezes o instrumento apenas de forças que acham escondidas no seu interior". Assim é que "Menino de Engenho" (1932), "Doidinho" (1933), "Bangüê" (1934), "Usina" (1936) e "Fogo Morto" (1943) reconstituirão o apogeu e a decadência da civilização do açúcar no Nordeste latifundiário e patriarcalista. Apesar de suas obras poderem ser classificadas em ciclos - ciclo da cana-de-açúcar: Menino de Engenho, Doidinho, Banguiê, Usina e Fogo Morto; ciclo do cangaço, misticismo e seca: Pedra Bonita e Cangaceiros; obras independentes dos ciclos: Moleque Ricardo e Pureza; tentativa de fuga à paisagem nordestina: Riacho Doce, Água-Mãe e Eurídice; retorno á paisagem nordestina: Meus Anos Verdes, - o Regionalismo foi, sem dúvida, a preocupação mais decisiva na formação do escritor paraibano. Suas investidas contra o modernismo decorrem, em grande parte, dessa preocupação regionalista. O próprio contato com Gilberto Freyre aguçou esse sentido do regional. a criação de mecanismos mais eficientes e mais próximos do controle, por força da descentralização republicana.

As elites tradicionais da região sentiam que as mudanças afetavam não só o seu poder de mando, mas também o próprio futuro de suas posses, com a ameaça da industrialização no campo. Por industrialização se entende não só o desenvolvimento das forças produtivas e mecânicas, mas a aceleração da divisão social do trabalho, ${ }^{6} \mathrm{com}$ a submissão da economia agrária às necessidades industriais e aos critérios do capitalismo (racionalidade, rentabilidade, produtividade, expansão).

A trajetória da família Cascudo é o resultado desse contexto. Originária do interior norte-riograndense, ela constitui-se numa poderosa elite local. O avô materno, Manoel Fernandes Pimenta, era um aristocrático fazendeiro e proprietário de escravos. O avô paterno era Antônio, da família Justino de Oliveira, depois chamado de Cascudo, como o próprio Câmara Cascudo nos diz:

Cascudo não denomina realmente minha família paterna, mas, Justino de Oliveira, Gondim, Ferreira de Melo, Marques Leal. Meu avô, Antônio Justino de Oliveira era nos últimos anos, chamado o velho Cascudo, pela devoção ao Partido Conservador, também com essa alcunha. Dois filhos, Francisco, meu pai (1863-1935), e Manuel (1864-1909), tiveram a idéia de juntar o cascudo ao nome, vocabulário que jamais meu avô pronunciou (1968, p.32).

O Partido Conservador, com o qual Antônio Justino de Oliveira tinha proximidade, representava a aristocracia rural da época da Monarquia. Composto por grandes fazendeiros, seus membros eram escravocratas e só aceitavam reformas políticas que não afetassem seus privilégios e seu exclusivismo político, mantendo o poder por meio do apadrinhamento e do controle das províncias. Foram anos de gloria, em que os senhores, proprietários de terras, dominavam a região do alto de velhas casas-grandes e não respeitavam as leis da cidade, devido às redes de poder e prestígio que teciam, seja através do enriquecimento material, seja das decisões políticas.

${ }^{6}$ Sobre essa questão, ver Durkheim, [1893] (1960). 
A formação tradicional da elite "nortista" impedia que ela acompanhasse o ritmo das mudanças que se passavam na sociedade e na economia. Ou seja, essa elite foi incapaz de evitar aquilo que Gilberto Freyre (1974), no livro Ordem e Progresso, chamou de "desintegração da sociedade patriarcal”, que deu origem à família conjugal moderna (Calmon, 1939; Pinho, 1946; Levi, 1996). A estratégia endogâmica dessa família viabilizava a prática do casamento entre parentes como mecanismo de manutenção de grandes propriedades rurais. Esse modelo de família possibilitava a ampliação do espaço, a progressão do tempo e a perpetuação do poder.

Nos idos de 1878, havia muitos engenhos da região que ainda executavam o mesmo processo de fabrico de açúcar há duzentos anos. A essa tecnologia antiquada sobrepõe-se a emergência das usinas em substituição aos antigos engenhos, o aumento da produção bovina no sul e a consequente queda da produção local. Como nos diz Freyre: “... compreende-se que ao se definirem tais efeitos, tenham-se arruinado, ou pelo menos decaído do seu antigo esplendor na mais tristonha mediocridade da vida, famílias patriarcais do Nordeste" (1974).

Esse contexto remete à crise da sociabilidade colonial, fundamentada em relações pessoalizadas e paternalistas entre os senhores e seus comandados e à sua lenta substituição por novos códigos sociais baseados no individualismo e na despersonalização das relações familiares. Aos herdeiros da elite "nortista" rural em decadência restava acionar o capital das relações sociais que lhes restou. Uma vez rompidas as ligações com o universo patriarcal de seus pais, restava a busca de refúgio em outros domínios: migrar para a cidade, usando o que restava do prestígio do nome da família, aliar-se com os membros dos grupos dirigentes locais e negociar empregos públicos como condição de manter os poucos bens que lhes restavam.

O Senhor Francisco Cascudo, pai de Câmara Cascudo, adotou essa estratégia para permanecer. A crise da produção agrícola leva-o a não exer- cer uma atividade rural, dando continuidade à tradição de sua família. Torna-se chefe da polícia local (delegado de militar) na cidade de Caicó, interior do Rio Grande do Norte. Depois, por influência do chefe político de lá,7 Luis Pereira Tito Jacome (1835-1906), é levado para Natal e recomendado ao governador Pedro Velho, tornando-se alferes do Batalhão de Segurança da Guarda Nacional em 31 de julho de $1892,{ }^{8}$ lá permanecendo até o ano de 1900, quando já alcançava o posto de tenente, muito embora chamado e conhecido por todos como coronel Cascudo. Esse momento da história paterna não é apagado por Câmara Cascudo em sua biografia.

Quando nasci meu pai era tenente da Quarta Companhia do Batalhão de segurança, deixou depois o quartel pelo comércio, mas conservou o orgulho da farda, a vaidade de haver pertencido à velha corporação centenária e sem manchas. Criou-me ouvindo histórias da caserna na luta com os cangaceiros, figuras heróicas de cabos e sargentos, os combates ferro-frio no silêncio das estradas sertanejas, o estompido das comblaims, o tiro retumbante dos vargantes de ordenança. Daí em retentiva infantil a intuição de estar espiritualmente ligado ao batalhão de segurança, desde o tempo em que usavam gorro de duas pontas com bolota oscilante e espada rabo-degalo (1940, p.12).

Em 1900, o coronel Cascudo foi exonerado da Guarda Nacional e tornou-se comerciante, comprando a loja de ferragens e miudezas de José Gomes Tinoco e transformando-a numa das maiores lojas de ferragens de Natal, O Cometa. Tornou-se também dono do armazém O Profeta, que fornecia as embarcações costeiras. No dia 7 de Setembro de

\footnotetext{
Era comum, na segunda metade do século XIX e primeira metade do século $\mathrm{XX}$, os pertencentes às famílias de proprietários rurais que se arruinaram sobreviverem à custa de empregos no serviço público, angariados com os políticos locais em troca de favores e apoio político.

${ }^{8}$ Podemos distinguir três fases diferenciadas da Guarda Nacional brasileira. A primeira fase, a da menoridade, vai de 1831 até a reforma da lei em 1850, quando a corporação, como força de grande contingente popular, atuou de forma direta e intensa na campanha da pacificação. A segunda fase, que abrangeu o segundo reinado de 1850 a 1889, caracterizou-se pelo início da aristocratização de seus quadros dirigentes, transformando-se depois em milícia eleiçoeira - força de oficias sem soldados. Finalmente, na terceira fase, a Republicana, irá verificar-se a absorção da milícia cidadã pelo exército, como força de segurança, assim conservando-se até o seu total desaparecimento. Holanda (2004, p.274).
} 
1914, fundou o jornal A Imprensa (segundo Câmara Cascudo, sem auxílios alheios; foi o jornal dos novos, a voz operária, sem compromissos políticos, subjeções limitadoras), ${ }^{9}$ em oposição ao Diário de Natal, que era o órgão da oposição, instalado precariamente na rua da Conceição, na Cidade Alta, e mantido pelo professor Elias Antônio Pereira dos Santos (1848/1906), e A República, órgão do Governo, na Rua Correia Teles, prolongamento da rua Dr. Barata. A República era mantida pelos cofres oficiais. Segundo Sérgio Miceli (1979, p. 100-101), a iniciativa de fundar jornais foi seguida por muitos herdeiros de antigas famílias tradicionais, pois viam a possibilidade de trazer de volta o prestígio da família e reorientar as aspirações de mando em âmbito local. (Miceli, 1979)

Outro fato interessante - que a criação de jornais por famílias ex-proprietárias de terras possibilita inferir -é que, revendo rapidamente a história, a ocupação do espaço brasileiro está diretamente relacionada à distribuição do trabalho - os que produzem e os que controlam os lucros. Mas, certamente, muitas famílias que perderam o controle econômico, através de um processo complexo de reconfiguração, procuraram manter um papel controlador - nesse caso, o controle das ideias, da crítica e dos processos -, sobrepondo-se à lógica da produção.

A prosperidade econômica possibilita ao senhor Cascudo comprar, do arquiteto Herculano Ramos, em fins de 1913, a Vila Amélia, no Tirol, região de chácaras e quintais. Lá reunia artistas e cantores nas noitadas e festas, em sua grande casa. Possibilita-lhe também a criação e colaboração do bispado, do asilo de mendicidade, da companhia de bombeiros e das estradas de automóveis para o Seridó.

${ }^{9}$ A descrição do jornal feita pelo folclorista revela a sua percepção acerca dos empreendimentos de seu pai. Essa situação é exemplar dos valores próprios do modelo de família patriarcal, como a subserviência e o reconhecimento pleno de tudo que era planejado, idealizado por aquele que liderava o tronco comum. Portanto, a visão de Câmara Cascudo era, de fato, romantizada e harmoniosa, tal como fora reproduzida em suas biografias e obras. Por isso a necessidade de não aceitamos as coisas como parecem, ou seja, as verdades instituídas por ele (Cascudo, 1968. p.36).
Por volta de 1930, o pai de Câmara Cascudo, que até então gozava de boa situação financeira, começou a enfrentar sérias dificuldades, por confiar na palavra dos "amigos", que lhe faziam débitos e não pagavam. Para resolver seus problemas, o Senhor Cascudo hipotecou seus bens e não pôde salvar sua dívida executada. Enquanto isso, sua esposa perdia as jóias e assistia ao declínio da família. Apesar de ser visto como o investidor, o pai provedor, não conseguiu manter a sua riqueza e levou a família à decadência.

Em 1918, Câmara Cascudo iniciou o curso superior de medicina na Bahia, deslocando-se para o Rio de Janeiro no período entre 1919 a 1922. Porém, no quarto ano do curso, as condições de seu pai levaram-no a interromper os estudos. Em 1924, ingressou na Faculdade de Direito do Recife, formando-se em 1928 e seguindo a trajetória intelectual da maioria dos filhos da antiga elite "nortista", pois o curso de Direito era reservado às pessoas que dispunham de boas condições econômicas. Naquela Faculdade estudaram escritores como José Lins do Rego, José Américo de Almeida e outros filhos de senhores, proprietários de terras e engenhos.

A partir do jornal A Imprensa, órgão mantido por seu pai, Câmara Cascudo publicou sua primeira crônica, "Bric-à-Brac", segundo Oliveira Gibson, título bem ao gosto do início do século, onde tratava das variedades da província. Fazia pequenas críticas literárias às leituras de certos autores nacionais e internacionais que lia e que conhecia e com os quais conversava. Nesse texto, desenvolveu seu estilo, bastante influenciado pela convivência com Henrique Castriciano, a pessoa que o conduziu a leituras refinadas, como as dos livros franceses que seu pai importava da Europa, além de autores brasileiros que gostavam de ler, dentre os quais se destacava Machado de Assis e Tobias Barreto. ${ }^{10}$

Em 1921, publicou seu primeiro livro, Alma Patrícia. Para Gibson Oliveira, Alma Patrícia tornase importante porque é um livro pioneiro. Cascudo

${ }^{10}$ Oliveira (1999, p. 30). 
consegue escrever sobre o autor natalense, fato inédito para aquele começo dos anos 20, quando o mundo se voltava para a França. O natalense só falava em Paris, tinha um olhar "afrancesado". Havia, no Brasil, uma Belle Époque tardia, tanto no Rio de Janeiro e em São Paulo como em Natal, e seus seguidores exercitavam, naquela época, um jeito “parisiense de vida”. Porém a decadência do coronel Francisco Cascudo (seu pai), além de não assegurar o término do curso de medicina ao filho, também não lhe deu condições para viver apenas de escrever artigos, revistas e livros, pois o mercado livresco da época não permitia vantagens em tal ocupação. Dessa forma, após o término do curso de direito, os laços de amizade e o nome da família vão ser fundamentais para seu ingresso do mercado de trabalho, com a ocupação de empregos públicos angariados com os amigos influentes da política do Rio Grande do Norte.

Toda a carreira profissional e intelectual de Câmara Cascudo é permeada por influências políticas, embora sua autobiografia e as biografias sobre ele destaquem o seu amor pelo magistério. É necessário fugir dessa verdade, situando-o em seu contexto, para perceber que a carreira de professor lhe foi imposta pela decadência do pai e era uma das profissões de fácil ocupação a partir de amizades políticas.

São relações de agradecimento e dependên-

\section{CÂMARA CASCUDO E SEUS OUTROS}

Nasci na Rua Senador José Bonifácio que ninguém sabia em Natal quem fora, toda a gente a dizia virgens, no Bairro da Ribeira.

A parteira foi a velha Bernardina Nery, falecida nas rocas em 25 de agosto de 1922, com 82 anos. Apanhara mais de 800 crianças. Meu pai era tenente do Batalhão de Segurança e pagou dez mil-réis. Passeando, aflito, pelo corredor, ouviu meu choro e perguntou: "homem ou Mulher?" -

"ele veste calças!"-, respondeu mãe Bernardina. Nunca me fantasiei de menina, nem mesmo o saiote rild em festa escocesa.

Nasci numa sexta-feira, dia de São Sabino, 30 de dezembro de 0898, às 5:30 da tarde... Nasci meia hora depois do apito da fábrica, pregão sonoro da tarde natalense. Minha mãe fizera promessa para dar-me o nome de "Luís de França", mas meu pai vetou o "de França", por causa de um soldado desse nome, muito cachaceiro e rixento, no quartel, então na Silva Jardim, esquina da Frei Miguelino.

[...] Meu pai viu morrer três filhos crianças e apenas o quarto, Luis, sobreviveu, registrou-o Luís da Câmara Cascudo, para perpetuar a tradição, nascida com ele e o mano Manuel (1976, p.3-4).

Este trecho do livro Seleta, escrito por Câmara Cascudo, repete um tema recorrente na maioria dos discursos memorialísticos e biográficos escritos por homens que viveram a infância entre o final do século XIX e o começo dos anos trinta do Século XX - o pai como ponto de partida de toda narrativa. É o seu nome que dá origem e sentido a toda trajetória da vida de quem é biografado. O nome serve de origem a uma identidade de sujeito masculino que se elabora como sua projeção. Os discursos biográficos se obstinam em não pensar em papai e mamãe, como forma pessoal e parental, como construções históricas, lugares de sujeitos elaborados culturalmente, ponto de chegada e não ponto de partida de qualquer identidade, como trajetos e devires e não como pessoas.

Seu nascimento foi acompanhado por um personagem marcante em suas biografias e em sua vida, seu pai, aquele que lhe deu um sobrenome, pagou o seu parto, esteve aflito na hora de seu nascimento e tornou-se definidor em sua identidade.

Câmara Cascudo começa a construção de sua imagem a partir de outra imagem, a de seu pai, o Coronel Cascudo, "homem respeitado por todos pela dignidade pessoal”, "o investidor de iniciati- 
vas úteis", "homem de bom coração que hipotecou sua casa no Tirol, mas não cobrou aos seus devedores", ${ }^{11}$ o aristocrata, o pai atencioso que educou o filho com professores particulares e livros que trazia de longe (da Europa), o patriarca do Tirol que deixou 1.200 afilhados, que reunia e dava abrigo aos amigos em sua grande casa.

Aqueles que conheceram meu pai recordarão o esplêndido conservador que ele era. O vocabulário expressivo, a gesticulação viva, sublinhada pela malícia dos olhos azuis, as várias inflexões da voz, a imperturbabilidade dos momentos hilariantes, faziam-no ouvido onde começasse a evocar um fato antigo ou uma anedota do seu tempo (1983).

Esse trecho é constitutivo dos discursos memorialísticos de Câmara Cascudo e reflete a imagem que ele consagrou de seu pai como um modelo dominante e exemplar da figura masculina de uma época. Trata-se da memória como um elemento constituinte do sentimento de identidade. O pai (Francisco Cascudo) se torna inaugural para a história do filho (Luís da Câmara Cascudo). Sua história é uma continuação da história do pai e, por isso, a recorrência à imagem do pai em sua biografia - aquele que lhe transmitia um sangue, uma hereditariedade, um nome de família, um status social e político.

Segundo Michael Pollak, (1989) ninguém pode construir uma autoimagem isenta de mudança, de negociação, de transformação em função dos outros. A construção da identidade é um fenômeno que se produz em função dos outros, com referência aos critérios de aceitabilidade, de admissibilidade, de credibilidade, e que se faz por meio da negociação direta com outros. A memória é um fenômeno construído: quando Câmara Cascudo recorda seu pai, ele está dando uma organização

11 "Era dono da maior loja de ferragens de Natal "o Cometa” comercializava crédito, faturas altas. Homem que acreditava na palavra, os clientes que permanecessem descansados, o crédito de sempre estaria aberto, não a troco de duplicata, mas da palavra. Não imaginava ele que os 'cabelos de bigodes', antigos afiançadores da palavra empenhada, não existiam numa pequena província onde só circulavam dez carros e os amigos o enganaram... Francisco Cascudo, com a fortuna abalada, nunca queixou-se de nenhum freguês, tampouco ingressou com ações para débitos ou falou no assunto." Oliveira (1999, p. 34). aos acontecimentos que marcaram a vida dele em sintonia com a elaboração da sua própria vida.

Câmara Cascudo traduz a imagem de seu pai como a do grande patriarca, do chefe da família, do responsável pela geração do capital econômico, simbólico e cultural. Um homem ousado e provedor das necessidades da sua família que, por isso mesmo, investe na perpetuação do seu nome.

A célula mater (a família Cascudo) é constituída por essa figura do pai supremo, romantizado e idealizado por Câmara Cascudo e também por outro membro, a mãe, que, apesar de sua importância para a família, é pouco lembrada em relação ao pai. Quando aparece, é de forma secundária e presa a um discurso cristalizado na idéia da esposa ideal, da mulher submissa.

Minha mãe foi como ela dizia, mulher de sua casa, o jardim, os pássaros, os quadros de esposa alemã, cozinha, igreja, criança e roupa. Jamais frequentando alta sociedade, etiquetas, elegâncias, imposicões sociais. Quando rica estava sem possibilidade de apartação. Vestia-se bem e adorava cinema, mas manteve o seu lar com interesse, atenção carinhosa, cumprindo a missão humilde, modesta, retratava as velhas damas de outrora. Amava seu pequeno mundo e nunca passou das emoções do cotidiano. Conservou a fé inabalável, rosário e promessas para todos os problemas diários.

No declínio econômico, desfez-se de quase todas as jóias para ajudá-lo. Nunca falou esse sacrifício. Tinha um sorriso triste quando via, na mesa, uma jóia no peito, braços ou dedos da mulher de um credor impaciente de seu Chico (Cascudo,1968, p.42)

Nessa narrativa, Câmara Cascudo ressalta a figura materna. Ele a coloca como um exemplo de mulher e esposa. Mas o que era ser uma boa mulher na visão dele? Passiva, submissa, religiosa, conformada? Se era essa a imagem que o regionalista queria retratar da mulher da sociedade daquela época, parece ser uma visão fortemente influenciada por uma série de elementos distintivos, discriminatórios e hierarquizados, que se transformaram em discursos doutrinários, capazes de instituir estereótipos a partir de uma visão, embora dominante, sempre determinada. Porque, nas palavras de Bourdieu (2002, p. 13), as visões e discursos, por vezes inconscientes, são incorporados pela ação de esquemas e estruturas históri- 
cas que se transformam em instrumentos de reflexão, ou "categorias de entendimento".

Enquanto o Senhor Cascudo aparece nas biografias e autobiografias do filho como um homem ativo, social, política e economicamente, como propagador do nome da família, símbolo de autoridade e respeito - mesmo tendo levado a família à falência-, a senhora Ana Maria da Câmara Pimenta, Ana da Câmara Cascudo, mal tem o seu nome citado nas biografias. A referência a ela é sempre na figura da mãe, a mulher bondosa, religiosa, recatada ao lar, simples, carinhosa, obediente, conformada com o seu lugar (cozinha, igreja, criança e roupa).

Ana da Câmara Cascudo parece não ter imagem própria, apenas como complemento de outras vidas ou histórias, do seu marido, do seu filho, da sua família. Sua existência parece estar associada a um papel, a uma função: a de esposa do senhor Francisco Cascudo e de mãe de Luis da Câmara Cascudo. Seu lugar na história é semelhante ao da maioria das mulheres das famílias conservadoras, aristocráticas, autoritárias, colonialistas - o confinamento ao lugar da casa e dos afazeres domésticos.

Câmara Cascudo enfatizou esse discurso da mulher frágil, dependente e relegada ao espaço privado. Essa mulher, ao realizar atividades fora de casa, estaria se desviando das funções tradicionalmente desempenhadas pelas mulheres, ou seja, das funções domésticas. Em artigo publicado no jornal A República, sobre o casamento de Dona Cândida, expressa a visão de mulher-homem: "Com a morte do marido, Dona Luzia Antônia ficou sendo o homem da família, com uma energia masculina conseguiu salvar o patrimônio da tradicional família." (Cascudo, 1940). Nessa passagem, o folclorista legitima a idéia de que só o homem pode prover a sua casa e não a mulher, como se isso fosse anormal ou impossível.

A passividade feminina, que Câmara Cascudo vê como natural em sua mãe, consiste apenas em assistir ao fracasso de um marido, que - apesar descrito nos discursos memorialísticos como um homem investidor, respeitado e ousado -, não resolveu a crise econômica que se abateu ao longo do tempo em suas atividades de empresá- rio. Dessa forma, parece que, para ele, o lugar de sua mãe seria apenas esse, o da passividade diante da situação, sem questionar o fracasso do marido, ou mesmo fazer qualquer intervenção, pois o declínio econômico de famílias tradicionais, especificamente na região Nordeste, não foi um fato que afetou apenas a família Cascudo.

Com a crise que abalou as famílias oligárquicas tradicionais do Nordeste, com a desclassificação social do poder paterno no período entre a implantação da República e a década de 30, houve o "processo de feminização", ou seja, as mulheres entraram em cena no exercício de atividades econômicas. Pertencentes às antigas famílias dominantes, herdeiras de um patrimônio de amizades, muitas mulheres passaram a se dedicar profissionalmente ao trabalho de costura como uma fonte de renda para auxiliar nas despesas da família. Outras passaram a vender doces e bolos, cujo consumo e segredo de preparo, durante gerações, foram exclusivos de suas famílias. Agora, elas se viam "obrigadas" a torná-los públicos para aumentar a renda domestica.

Em seu discurso, ele incorpora a idéia do homem como figura pública e chefe da família, e da mulher como condenada à esfera privada, como dona da casa.

O homem corporifica a idéia de autoridade, como mediação da família com o mundo externo. Ele é a autoridade moral, responsável pela respeitabilidade familiar. Sua presença faz da família uma entidade moral positiva, na medida em que ele garante o respeito (Sarti, 2003, p. 63).

Câmara Cascudo estabelece regras implícitas de convivência cotidiana familiar, onde se percebem as demarcações de hierarquias que reafirmam as fronteiras entre o masculino e o feminino.

Quando Câmara Cascudo fala de seus pais, ele está construindo a família Cascudo. Para isso, ele toma o modelo da família tradicional, patriarcal, com subordinação dos sexos e o forte patria potestas (poder paterno legal). Seu pai aparece nas suas autobiografias e obras como o dominador, o membro ativo social, política e economicamente, aquele que exerce plenos poderes na casa. A sua mãe é resgatada como a dona de casa, a esposa 
ideal e passiva diante das vontades do marido. A família é tomada como uma referência simbólica fundamental, que permite pensar, organizar e dar sentido ao seu mundo social.

Essa visão de família patriarcal e nuclear de Câmara Cascudo é compatível com a difusão do discurso científico, jurídico e popular, o qual, segundo Jeni Vaitsman (1994), tornou-se dominante em certa época, a respeito das características próprias da natureza de cada sexo:

... as mulheres eram classificadas como fisica-
mente frágeis e, por isso, naturalmente delica-
das, submissas e afetivas, e os homens como fisi-
camente fortes, e, portanto, dominantes, vigoro-
sos e intelectuais. A delicadeza e a afetividade
feminina coadunavam-se muito mais com o sen-
timento de amor do que a virilidade masculina.
Contradição entre os dois seres tão naturalmente
distintos que seria resolvida pelos papéis com-
plementares na família conjugal, através dos quais
a natureza feminina realiza-se como mãe e espo-
sa devotada e masculina como pai, responsável
pela provisão material e moral da família
(Vaitsman, 1994, p. 56).

A família Cascudo, retratada por Luís da Câmara Cascudo, segue uma hierarquia: o pai absoluto, corajoso, bondoso, honrado e respeitado; a mãe passiva, bondosa, cristã, dona de casa, respeitada, recatada e simples; o filho grato, educado e obediente, cujos elos de obrigações em relação a seus familiares prevalecem sobre os projetos individuais. Os valores levantados por Câmara Cascudo são os mesmos valores patriarcais que legitimaram as normas para a regulamentação dos papéis da família ideal e oficial. "Como um código moral familiar, hierárquico e patriarcal, expresso nas relações entre homem e mulher, entre pais e filhos" (Sarti, 2003, p.20).

Como Câmara Cascudo constrói a noção de família como uma ordem moral, referencia para pensar o mundo onde se situa? Ele pensou a família a partir do caráter sagrado, uma união (homem e mulher) baseada na tradição católica. O pai como cabeça da casa e, daí, a supremacia masculina; e a mulher como edificadora do lar e, por isso, sua reclusão ao ambiente doméstico. Essa visão de família é limitadora, pois exclui qualquer outro modelo. E, nisso, concordamos com Uziel (2004), quando afirma ser a família uma construção social, "um conjunto de indivíduos aparentemente ligados entre si - seja pela aliança (o casamento), seja pela filiação, seja mais excepcionalmente pela adoção (parentesco) - e vivendo sob o mesmo teto (coabitação)" (2004, p. 89).

Os laços de amizade elencados por Câmara Cascudo remetem a algumas questões que as biografias não explicitam. Os nomes que permeiam a sua vida são de homens da elite letrada local, políticos, fazendeiros, como Pedro alexandrino dos Anjos, Francisco Ivo, Luís Antônio, Manuel Garcia, Joaquim Lourival Soares da Câmara, Juvenal Lamartine de Farias, Ubaldo Bezerra, José Augusto Varela, Sílvio Piza Pedrosa Walter Wanderley, Moreira da Costa Lima, Mariano Coelho Afrânio Peixoto, Gustavo Barroso, Rodolfo Garcia e outras pessoas próximas ao poder e que o auxiliaram, patrocinando suas publicações, viagens e pesquisas. Sua biografia é repleta de homens. As poucas mulheres que aparecem são a sua mãe, as professoras e Luiza Freire. Todas numa posição secundária em relação aos homens. As mulheres são vistas como frágeis, ligadas ao lar e aos ofícios ditos femininos, o que marca a supremacia do masculino em sua visão de mundo e no conceito de cultura. Os homens são apresentados como ágeis, em torno dos quais as histórias são narradas. Valentes como os cangaceiros, os policiais, os vaqueiros, os boiadeiros. Atuantes na sociedade, apresentam-se como os cantadores, poetas, comerciantes. Respeitados como os coronéis, os senhores de engenho, os fazendeiros, aristocratas. As mulheres aparecem como donas de casa, zeladoras da família. Indefesas, sempre precisavam do homem para resguardá-las do mal. E espertas para livrarem-se da fúria dos companheiros quando faziam algo errado. Recatadas ao ambiente doméstico, à espera do "príncipe encantado".

Devemos entender e questionar a formação discursiva ${ }^{12}$ presente nesses enunciados, pois ela

${ }^{12}$ Compreendo como formação discursiva o conjunto de regras que caracterizam um determinado discurso e permite relacioná-lo em um sistema comum. São relações entre objetos, entre tipos e enunciados, conceitos e estratégias que possibilitam a passagem da dispersão (considerando o discurso como dispersão) à realidade. Em outras 
torna ainda mais visível as diferenças entre homens e mulheres, as quais produzem efeitos diversos - autoridades, primazias, hierarquias e exclusões -, cristalizando-se em instituições e verdades, engendrando relações de poder e força.

A visão que Câmara Cascudo elaborou para o que seria a família, seu pai e sua mãe, é marcante para entendermos como isso remete ao discurso da diferenciação nos papéis dos homens e das mulheres em suas biografias e obras. Os personagens principais de suas histórias são coronéis, cangaceiros, bandidos, valentões, cabras safados, defensores dos injustos e dos francos, reis arrogantes, pobres lavradores, contadores de histórias, pescadores, caçadores. Sempre personagens ativos e protagonistas das histórias. Já as mulheres aparecem para dar afirmação a uma ordem social regida pelos homens. São elas frágeis, dependentes, que precisam do homem para proteger sua honra, jovens, belas, sonhadoras, ou senhoras contadoras de histórias. A mulher é um ser que foi silenciado, invisibilizado, que quase nunca faz a história, mas é parte dela.

\section{O LUGAR DA MEMÓRIA: Câmara Cascudo e a imagem de si mesmo}

Era um menino rico, nascido em Natal, Rio grande do Norte, a 30 de dezembro de 1898 . O pai, coronel que perseguiu cangaceiros, o comerciante mais abastado da cidade. A mãe, descendentes de aristocratas, sabia piano e falava francês. O garoto passou infância de mimos e cuidados, já havia perdido três irmãos. 'Fui menino magro, pálido, enfermiço, cercado de dietas e restrições alimentares. Não corria, não saltava, nunca pisei areia, nem andei descalço, jamais subi a uma árvore, cuidado com fruta quente, sereno, vento encanado!', relata em o Tempo e Eu (1968). Amarrado aos livros, colecionava estampas de santos e histórias, na adolescência, o contato com o Sertão. Aos 16 anos já anotava tudo o que via: causos, cantigas, lendas, receitas. Em Vaqueiros e Cantadores (1939), contará: vivi no Sertão típico, agora desaparecido. Cortei macanbira e xique-xique para o gado nas secas. Banhei nos córregos no inverno. Peguei tatus de noite, com fachos e cachorros amestrados". ${ }^{13}$

palavras, são regras capazes de reger a formação do discurso, explicando, ao mesmo tempo, como discursos aprecem e se distribuem no interior de um dado contexto social. A esse respeito, ver Foucault (1986. p. 35-45).

${ }^{13}$ Almanaque Brasil de Cultura Popular, positivo. p.14.
O trecho em epígrafe aborda uma visão dos outros sobre Câmara Cascudo, mas que ele mesmo legitimou em suas biografias. A imagem do menino doente torna-se um marco na elaboração da sua idéia de família, os valores que a influenciaram, as imagens que ficaram marcadas, o momento histórico em que ocorreram e as personagens de sua elaboração.

Entre 1910 e 1913, Câmara Cascudo esteve à beira da morte e foi com sua mãe para o Sertão da Paraíba e o Rio Grande do Norte, procurando curar-se dos males que ameaçavam caminhar para a tuberculose. Esse é um fato concreto na vida dele, mas o que nos chama a atenção é como esse acontecimento se torna a base para, em suas obras, discorrer sobre a ideia de família, o que se estende também para seus comentadores. As limitações de seu corpo pela doença - não correr, saltar, pisar na areia, andar descalço, subir em árvores - levaramno a uma vida reclusa. E sua infância, como ele nos diz em Histórias que o tempo leva, foi triste e sonolenta "como um animal raro, no meio dos agasalhos de lã e coberto de linhos aquecidos. Vida livre, tarde de sol, caminhadas pela estrada poeirenta, nunca conheci!”. E o fato de ser filho único de pais ricos, criado com zelo e temor das doenças que "levaram" seus três irmãos na infância, aparece como condutor natural de sua escolha em direção aos livros, não havendo mais nada a fazer.

A infância isolada dos amigos, uma meninice solitária e doente, cercado de brinquedos, mas sem companheiros de folias, é preenchida, na biografia, pela prática da leitura, o que surpreendia seus professores e os amigos de seu pai. A doença é legitimada como um caminho para a leitura, mas também a responsável pela sua ida ao Sertão e pelo contato com o que ele chama de literatura popular.

O menino doente contava com o apoio da mãe, que cuidava da sua saúde e, ao mesmo tempo, lhe dava minos de um filho único. Era sua companheira inseparável nas horas de solidão.

Essa trajetória do menino doente é interessante, pois se torna um marco definidor de seu destino, de sua ida ao Sertão na infância: “... menino, fui com minha mãe para o Sertão, a conse- 
lho do Dr. Joaquim Murtinho, enrijar os pulmões. Sertão sem estradas de rodagem, luz elétrica, automóvel”(Cascudo, 1976, p. 6-7). A doença que o acometeu fez com que seus pais o levassem ao campo para se curar longe da tumultuada vida urbana. Na cidade, a presença dos pais era motivo de restrições, pois o jovem vivia sob constante vigilância, não podia brincar nas ruas com os outros meninos, tomar banho de chuva, ficar exposto ao sol, ficar na areia descalço. Enfim, era uma vida limitada ao quarto e aos brinquedos. No campo, morando com seus avós, não havia restrições. $\mathrm{O}$ contato com a natureza e os amigos o levou a fazer muito daquilo que lhe era proibido pelos pais.

Que personagens marcam parte de sua memória sobre esse momento? O pai, o coronel que perseguiu cangaceiros, o comerciante abastado, lembrado pelo poder, respeito e prestígio junto aos outros e ao nome da família. Aquele que, em sua lembrança, foi o responsável pela prosperidade da família nessa época. A mãe, descendente de aristocratas, eterna companheira, mulher recatada, dedicada à educação do filho e ao marido. Seus novos laços de amizade, meninos do campo que o levaram para correr, pular, brincar, caçar, aproximando-o do espaço masculino, das conversas e dos lugares definidos para eles.

O tempo que passou no campo marcou sua vida e é registrado, nos prefácios e biografias, como a época áurea e inspiradora de suas obras. Essa época é retratada em diversas obras e assume um caráter definidor quando ele pensa a cultura, pois sempre parte desse mundo de sua lembrança de infância. E, embora fale dos costumes de um povo, sua visão parte do individual, especificamente das lembranças do tempo vivido no Sertão.

É partindo do campo que Câmara Cascudo descreve os costumes da região. As refeições, as festas, a criação do gado, a plantação de algodão, as vaquejadas, a instituição do compadrio. Morando com os avôs, entra em contato com cantadores e contadores de histórias, que se reuniam nos terreiros e nas varandas para louvar a saga dos valentes.
Todos sabiam contar estórias, contavam à noite devagar com gestos de inovação e lindos desenhos mímicos com as mãos. Ia eu ouvindo e aprendendo, não tinha conhecimento anterior para estabelecer confronto nem subalternizar uma das criatividades em serviço da outra. Era o primeiro leite alimentar da minha literatura. Cantei, dancei, vivi com todos os outros sertanejos do meu tempo e vizinhanças, sem saber a existência de outro canto, outra dança, outra vida (Cascudo, 1978, p.13).

O campo e a vida sertaneja da Paraíba e do Rio Grande do Norte tornam-se a base para Câmara Cascudo se referir à família. Para ele, tudo que presenciou no interior fazia parte de uma cultura prática, que agia e dançava nos terreiros, nas povoações e fazendas, nos cantos das missas, nas festas de gado, no fim de safra, nas palavras dos contadores de histórias. A essa cultura ele opõe outra, a que ele lia e leu quando voltou para Natal.

Dessa época, ele guardou na memória as histórias mais fantásticas da vida no interior, desde os matadores de onça aos mais altos expoentes de valentia e coragem sertanejas (aventuras do campeio, vinganças, crueldades, a derrubada do boi, a caça aos cangaceiros). Histórias da carochinha, fábulas de La Fontaine, as mil e uma noites, em que, quase sempre, havia um príncipe encantado, um rei generoso, uma princesa linda e ingênua e uma madrasta má, com o bem sempre vencendo o mal.

Que valores desse espaço são importantes para entendermos sua idéia de família e a diferenciação que dava aos lugares de seu pai e de sua mãe e, em consequência, aos de homens e de mulheres? A vida no campo é lembrada por Câmara Cascudo como um lugar do poder do homem, um espaço e um tempo em que o pai era o chefe inquestionável da família. A "patriocracia” era uma instituição sagrada e legitimada pelos costumes da época. "Diga o nome de seu pai e sua família e eu sei quem você é" - era assim que os indivíduos se tornavam conhecidos e respeitados na sociedade. Quem não tinha uma família de nome não era ninguém. O espaço masculino era marcado com a ação de cangaceiros, vaqueiros, boiadeiros, cantadores, cabras valentes. O homem é posto como o ser ativo, o protagonista das histórias. O povo que com- 
põe esse conceito e esse cenário emerge como ingênuo, crédulo e místico, não corrompido pela cidade, pois preserva os valores cristãos e mantém sua fé inabalável, recorrendo a crendices seculares para curar as doenças ou expulsar os males. É um povo trabalhador, que dedica seu tempo ao labor como uma prática sagrada, e ao mesmo tempo alegre, com suas festas populares, portador de uma cultura clássica. É atento à ordem, e a ordem é a religião. Nunca se opõe ao poder instituído, ao mandonismo local, o que o coloca numa condição de submissão e exploração.

Quando volta a Natal, Câmara Cascudo passa a estudar no Colégio Diocesano Santo Antônio, para ter amigos do mesmo sexo, uma vez que seu pai não gostava da educação mulheril que o filho teve no Externato Sagrado Coração de Jesus, das irmãs Andrade, onde foi posto pela mãe quando ainda estava no Sertão. Em 1913, seu pai comprou do arquiteto Herculano Ramos a Vila Amélia, no Tirol, região de chácaras e quintais, e contratava pianistas, tenores, declamadores e artistas em excursão para fruição literária da família. O pai enchia a casa de visitantes do interior, antigos amigos da família, e fazia festas e saraus algumas noites. O filho, como um príncipe, chamava a atenção pela coleção de livros que o pai trazia da Alemanha. Como o próprio Luís da Câmara fala, "depois de relativamente alfabetizado, adoeci da moléstia livresca: meu pai comprava tudo. Mandava buscar longe” (Cascudo, 1976, p. 7). A casa no Tirol tornou-se um lugar adequado para o contato com pessoas de outras localidades, como ele diz:

Tive as melhores e os maiores contadores de estórias, hóspedes de semanas e semanas, que vinham vender produtos das praias, ou de cantadores como Fabião das queimadas, que ficava meses conosco, cantando com a rebeca no peito e contando estórias do tempo em que tinha sido escravo. Todos os sábados a velha Silvana aparecia para almoçar e conversar, mentir, dizia minha mãe. Fora escrava de casa-grande, cantava, dançava, confidenciava os segredos dos antigos, excluindo-se, com visível modéstia (Cascudo,1976, p.7).

O espaço doméstico romantizado por Câmara Cascudo é esse em que seu pai era o personagem principal, o provedor da família, enquanto sua mãe era sempre relacionada ao lar, à família, à obediência ao marido. Nessa época, o jovem "príncipe do Tirol”, como era conhecido Câmara Cascudo nessa época, contava com os serviços de sua ama, a senhora Benvenuta de Araújo, companheira e contadora de histórias, muitas delas publicadas por ele. E ainda da senhora Luísa Freire, segundo ele uma mulher branca, analfabeta, que conviveu em sua casa de 09 de junho de 1915 até 23 de julho de 1953, quando faleceu. Era um jovem cercado de mimos e presentes de seus pais.

Em Natal, começa o curso secundário no Colégio Atheneu norte-rio-grandense. Em 1918, inicia o curso de medicina na Bahia. Em 1924, ingressa na Faculdade de Direito de Recife, e, em 1929, começa a sua carreira de professor, na condição de mestre interino no Atheneu.

É como professor que Câmara Cascudo se identifica e se legitima nas biografias e passa a ser visto pelos outros. É feita uma ligação desse ofício com a imagem do pesquisador popular. Ele se identifica como professor e explica por que não seguiu outras ocupações: "Fui para medicina, filho de pai rico, queria ter laboratórios de pesquisas e nesse tempo não havia cursos de laboratórios. Éramos pressionados a nos formar em Medicina. Meu pai empobreceu e eu ia sendo o pior medico do mundo” (Lima, 1998, p. 69). Essa saída da Faculdade de Medicina da Bahia e, posteriormente, do Rio de Janeiro, de 1919 a 1922, não foi espontânea, pois a crise financeira do pai o levou a largar mais rapidamente o curso. Sobre o curso de direito, ele explica: "Para não ser chamado de seu cascudinho, horrorizando mamãe fui para a faculdade de direito do Recife, três meses por ano, levando as economias pessoais, hospedado em pensões humildes e típicas" (Cascudo, 1968, p. 5). O curso de direito foi uma imposição familiar e social para a obtenção de um status, trajetória seguida por muitos filhos da elite letrada do Nordeste, herdeiros de antigas famílias ricas e poderosas da região, que iam para a Faculdade de Direito a fim de trazer o título de bacharel para a família. Mesmo quando o processo de decadência atingiu essas elites da re- 
gião, os pais faziam todos os esforços para encaminhar os filhos à faculdade, visando ao resgate social a partir de seus filhos como bacharéis.

Foi como professor que Câmara Cascudo quis ser identificado, e foi a partir dessa ocupação que ele partiu depois para o estudo da cultura, tornando-se conhecido como jornalista, historiador, etnólogo, folclorista, antropólogo e escritor interessado na região. Mas a escolha pelo magistério não foi natural como parece, pois ele a fez por necessidade. Para manter-se como tal, contou com o apoio de um político, Juvenal Lamartine, que o indicou para lecionar no Atheneu norte-riograndense em 1928.

A trajetória pessoal de Câmara Cascudo até o estudo da cultura não é tão linear como indicam suas biografias, uma vez que ela representa o medo da miséria e a insegurança profissional. Apesar de se dizer apenas professor, pelos laços de amizade, por influência política e pelo nome da família, ocupou diversos cargos no tribunal de justiça, foi diretor do Museu e do Arquivo de Natal, $3^{\circ}$ consultor geral do Estado e deputado estadual.

As biografias de Câmara Cascudo, embora não afirmem, mostram que sua atividade diária foi cercada pelo poder, pois ele viajava, jantava e veraneava com generais, coronéis e políticos de $\mathrm{Na}$ tal. Sua vida torna-se um exemplo da dependência que muitos escritores tinham de grupos da elite, situação em que o reconhecimento intelectual é dado pela posição social dos amigos. O lugar institucional de onde fala Câmara Cascudo implica uma aliança entre poder e saber.

Quais são as redes de memória que (re) criam a família Câmara Cascudo?

O pai era conhecido por diversos atributos: bondade, dignidade, respeito, atitudes e autoridade. Homem aristocrata, que deu uma educação esmerada ao filho, enchendo-o de livros (importados de longe) e de luxo e levando-o ao sertão para curálo da doença que o prejudicava. Figura base de sua vida, que lhe transmitiu uma herança simbólica e cultural com a narração de histórias fantásticas do seu tempo no Batalhão de segurança, as ações de cangaceiros e caçadores de onça, homens valentes.
A mãe era exemplo de esposa obediente, humilde, simples, caridosa, mulher do lar, que educou o filho com os fundamentos da religião cristã, dando-lhe uma educação de nobre, numa época em que poucos tinham oportunidade de se aprofundarem nos estudos. Uma mulher que marcou sua vida pela dedicação e pelos cuidados com o filho único, cuja condição de saúde era bastante frágil.

A infância doente, vivida no sertão, onde ele ficou um período considerável, propiciou-lhe o convívio com os valores de um povo simples e com uma cultura rica em suas manifestações, ameaçada de morte pelas inovações. Essa é uma fase de sua vida à qual ele faz referências na biografia como mais um fator na elaboração e autoconstituição de seu oficio de leitor, escritor e folclorista, como se toda a sua infância fosse apenas marcada pela doença e ela o tivesse levado ao exercício da leitura. Câmara Cascudo classifica o período da doença como um momento de reflexão sobre si mesmo, uma a oportunidade para o auto-encontro.

Sua ida para o sertão da Paraíba e do Rio Grande do Norte, segundo ele, propiciou-lhe um contato com as tradições populares (vaquejadas, a vida nas povoações e fazendas, a organização do trabalho, o horário das refeições, as roupas de casa, o vocabulário comum, os temperos, as condutas alimentares, as bebidas, as festas, a criação do gado, as superstições, assombros e rezas fortes) e com pessoas do campo (vaqueiros, fazendeiros, mãespretas, contadores e cantadores). São lembranças de uma época que ele nunca esqueceu e que marcou sua vida e sua escrita.

\section{À GUISA DE CONCLUSÕES}

Os discursos que Câmara Cascudo elaborou sobre sua família transformaram-na numa referência simbólica fundamental, que permite pensar, organizar e dar sentido ao seu mundo social. A família é a base para a formação de sua identidade, pois todo o projeto autobiográfico e biográfico sobre ele parte desse referencial. E, como ocorre em toda elaboração biográfica, a construção das 
imagens em torno dela são marcadas por lacunas, escolhas, exclusões e legitimação de alguns fatos.

A partir da visão desenhada por Câmara Cascudo acerca das experiências e dos personagens familiares, questionamos os fatos naturalizados, uma vez que muito do que foi construído por ele é resultado de uma realidade simbólica, que ordena e organiza formas de pensar e viver. No modelo de família do regionalista, predominavam valores tradicionais, e o padrão patriarcal está dentro de um contexto histórico, ao mesmo tempo de interesse e de escolha, pois, como todo modelo, ele é limitado e excludente. Sua elaboração atendia a um interesse pessoal, por ser mais um elemento constituinte do sentimento de identidade com suas lembranças e de autoconstituição.

Pensar o processo de constituição da família elaborado por Câmara Cascudo é perceber que, nas regras de convivência entre seu pai e sua mãe, havia uma demarcação explicita da hierarquia familiar, que reafirma as fronteiras entre o masculino e feminino. Na sua constituição do lugar do pai e da mãe, houve uma nítida seleção dos papéis.

O pai é sempre visto como o personagem principal de sua “trama biográfica”, aquele que deu início à sua história, lhe deu um nome de família, um status social, uma formação intelectual e uma segurança pessoal. Tornou-se uma referência obrigatória em suas biografias e obras: foi aquele que pagou seu parto, escolheu seu nome, comprou seus livros, pagou seus professores particulares, pôs na escola, contou estórias fantásticas, deixandolhe uma herança simbólica.

A mãe é sempre lembrada pela obediência a seu pai, uma mulher da casa, aquela que cuidou dele nos momentos da doença e lhe fez companhia na solidão. O lugar da mãe, na sua biografia, é o da personagem secundária, como se sua existência só tivesse sentido nesse contexto: o de dar apoio ao marido e educar o seu filho. Como ele concebe a mãe, nos seus discursos? A mulher do lar, humilde, atenciosa, educada, que sabia tocar piano e falar francês, que sempre cuidava da família e nunca deixava de fazer as tarefas domésticas, e que nunca se queixou da perda da riqueza provocada pelo marido.
Com base nessa construção de família e no respectivo código moral familiar, hierárquico e patriarcal - expresso nas relações entre homens e mulheres e entre pais e filhos -, este artigo, de modo objetivo, tentou apresentar o modo como as representações sociais de homem, mulher e família foram discursivamente construídas e cristalizadas na literatura folclorista de Câmara Cascudo. Por fim, descobrimos que certos valores re(elaborados) por ele apenas reafirmam a idéia de que os conceitos de família patriarcal, tradicional e nuclear são naturais e inquestionáveis, e tudo aquilo que vai de encontro a esse modelo é concebido como anormal e estranho, porque rompe com o padrão dominante.

(Recebido para publicação em fevereiro de 2008) (Aceito em novembro de 2008)

\section{REFERÊNCIAS}

BOURDIEU, Pierre. A propos la famille comme catregorie realisée. Actes de la Recherche en Science Sociales, Paris, Liber, n.100, 1993.

A ilusão biográfica. In: AMADO, Janaina; FERREIRA, Marieta Morais (Org.) Usos e abusos da história oral. Rio de Janeiro: Ed. FGV. 1996.

. A dominação masculina. Rio de Janeiro: Bertrand Brasil, 1999.

CALMON, Pedro. História da Casa da Torre. Rio de Janeiro: José Olympio, 1958.

CASCUDO, Luis da Câmara. Polícia mata-cachorro. A República, [S.l.],11 ago., 1940. p. 12.

O tempo e eu (confidencias e proposições). Natal: Imprensa Universitária, 1968.

Tradição, ciência do povo. Pesquisas na cultura popular do Brasil. São Paulo: Perspectiva, 1971

Seleta: organização, estudos e notas do professor Américo de Oliveira Costa. 2.ed. Rio de Janeiro: J. Olympio. 1976.

Literatura oral no Brasil. 2.ed. Rio de Janeiro: José Olympio: Brasília INL. 1978

Anubis e outros ensaios: mitologia e folclore. 2.ed. Rio de Janeiro: Funarte/INF; Natal: UFRN, 1983.

Ontem: imaginações e notas de um professor de província. Natal. EDUFRN 1999. p.100. Reimpressão.

Vaqueiros e cantadores: folclore poético do serão de Pernambuco. Paraíba, Rio Grande do Norte e Ceará. Rio de Janeiro: Ed. Ouro. 2000.

CERTEAU, Michel de. A escrita da história. Rio de Janeiro: Forense-Universitária, 1982. 
CORRÊA, Mariza. Repensando a família patriarcal brasileira. In: ARANTES, A. et al. Colcha de retalhos: estudos sobre a família no Brasil. Campinas, SP: Ed. Unicamp, [1982] 1993.

DURKHEIM, E. A divisão do trabalho social. 7. ed. Paris: PUF, [1893] 1960.

FREYRE, Gilberto. The patriarchalbasis of brazilian society. In: MAIER, Joseph; WEATHERHEAD, Richard (Ed.) Politics of change in Latin America. New York: Praeger, 1964

Sobrados e mocambos. Rio de Janeiro:José Olympio, 1967.

Ordem e progresso. 3.ed. Rio de Janeiro: J. Olympio; Brasília: INL, 1974.

FOUCAULT, Michel. As regularidades discursivas. In: Arqueologia do saber. Rio de Janeiro: FlorenseUniversitária, 1986

HOLANDA, Sérgio Buarque de. O Brasil monárquico: declínio e queda do Império: 3.ed. Rio de Janeiro: Bertrand Brasil, 2004. v. 4

LEVI, Giovanni. Usos da biografia. In: AMADO, Janaina; FERREIRA, Marieta Morais (Org.) Usos e abusos da história oral. Rio de Janeiro: Ed. FGV. [1977]1996.

LIMA, Diógenes da Cunha. Câmara Cascudo: leiro feliz. 3.ed. Rio de Janeiro: Pongetti,1998.
. A família Prado. São Paulo: Cultura, 1977.

MICELI, Sérgio. Intelectuais e classe dirigente no Brasil, 1920-1945. São Paulo: Difel; Rio de Janeiro: Difusão Editorial J.A, 1979

OLIVEIRA, Gibson. Câmara Cascudo: um homem chamado Brasil. Brasília: Ed. Brasília Jurídica. 1999.

ORTEGA, Francisco. Amizade e estética da existência em Foucault. Rio de Janeiro: Graal. 1999.

PINHO, W. História de um engenho no Recôncavo. Rio de Janeiro: 1946.

POLLAK, Michel. Memória, esquecimento, silêncio. Estudos Históricos, Rio de Janeiro, v. 2, n.3, 1989.

REGO, José Lins do. Usina. 13.ed. Rio de Janeiro: José Olympio, 1993.

SARTI, Cyntia Andersen. A família como espelho: um estudo sobre a moral dos pobres. São Paulo: Cortez, 2003.

UZIEL, Ana Paula. Homossexualidade e parentalidade. Ecos de uma conjugação. In: HELDORRN, Maria Luiza (Org.). Família e sexualidade. Rio de Janeiro: Ed. FGV 2004

VAITSMAN, Jeni. Flexíveis e plurais: identidade, casamento e família em circunstâncias pós-modernas. Rio de Janeiro: Rocco, 1994. 


\section{MATRIMONIAL BINDINGS, TRADITIONAL LINKS: the family as SELFCONSTITUTION in Câmara Cascudo}

\author{
Ramonildes Alves Gomes \\ Valdeci Feliciano Gomes
}

This paper aims to analyze the biography of Luís da Câmara Cascudo, trying to understand the historical and social foundations from which that folklorist legitimated positions about his father and mother and defined papers for men, women and family in the society of Northeastern Brazil. Therefore, Câmara Cascudo is not only what he says about himself, in his biographies and works, but also, what others said about him. His arguments are the result of relationships of multiples interests. It was by relating with the former and opposing the latter that this regionalist became a historical subject. Working with memory, understanding that it is not always a naive and disinterested elaboration, for being selective, we will analyze the constitution of the subject Câmara Cascudo and his other selves.

KEYWORDS: family, intersubjectivity; memory.

\section{LIENS MATRIMONIAUX, ATTACHES \\ TRADITIONNELLES: la famille, moyen d'autoconstitution chez Câmara Cascudo}

\author{
Ramonildes Alves Gomes \\ Valdeci Feliciano Gomes
}

Lobjectif de cet article est d'analyser la biographie de Luís da Câmara Cascudo en essayant de comprendre les bases historiques et sociales à partir desquelles ce folkloriste a réussi à faire reconnaître des postures envers son père et sa mère pour définir le rôle des hommes, des femmes et de la famille dans la société du nord-est du Brésil. Cependant, Câmara Cascudo n'est pas seulement ce qu'il dit de lui-même, dans ses biographies et dans ses œuvres, il est aussi ce que les autres ont dit de lui. Les arguments qu'il a construits sont le résultat d'un mélange d'intérêts. C'est en établissant une relation avec certains et en s'opposant à d'autres que ce régionaliste est entré dans l'histoire. La mémoire, tout en sachant qu'elle n'est pas toujours élaborée de manière ingénue et désintéressée, car elle est sélective, nous servira de base pour analyser l'avènement de Câmara Cascudo en tant que sujet et ses proches.

MotS-CLÉS: famille, intersubjectivité, mémoire.

Ramonildes Alves Gomes - Doutora em Sociologia pela Universidade Federal de Pernambuco. Professora do Departamento de Sociologia e Antropologia da Universidade Federal de Campina Grande. Coordenadora do Laboratório de Sociologia Aplicada - LASAP. Integra o Grupo de Pesquisa em Agricultura Familiar GPAF, desenvolvendo pesquisas na área de sociologia rural, políticas públicas e desenvolvimento rural. Suas mais recentes publicações são: Tomo 3 Teoria Social do Campesinato (2009); Revista Chonos (2008).

Valdeci Feliciano Gomes - Mestre em Sociologia pela UFCG. Integra o Núcleo de Pesquisa desenvolvendo pesquisas na área de Cultura e Identidades. 